\title{
La-doped titania nanocrystals with superior photocatalytic activity prepared by hydrothermal method
}

\author{
JIAO Yanchao, ZHU Mingfeng, CHEN Feng*, ZHANG Jinlong \\ Key Laboratory for Advanced Materials and Institute of Fine Chemicals, East China University of Science and Technology, Shanghai 200237, China
}

A R T I C L E I N F O

Article history:

Received 15 October 2012

Accepted 10 November 2012

Published 20 March 2013

\section{Keywords:}

Potassium octatitanate

Phase transition

La-doped titania

Photocatalytic activity

Hydrothermal synthesis

\begin{abstract}
A B S T R A C T
Potassium titanate (KTO) nanobars were synthesized by a hydrothermal method and used as a precursor to synthesize $\mathrm{TiO}_{2}$ nanocrystals. La doping of the $\mathrm{TiO}_{2}$ nanocrystals was achieved by introducing $\mathrm{La}^{3+}$ into the hydrothermal media. The hydrothermal transition of $\mathrm{KTO}$ to $\mathrm{TiO}_{2}$ was investigated under various conditions, finding that the $\mathrm{pH}$ of the hydrothermal media, the temperature, and the pre-treating procedure play important roles in the phase transition. X-ray diffraction and transmission electron microscopy were used to characterize the crystal phase and morphology of the samples and the transition process of the hydrothermal reaction. The content of $\mathrm{La}^{3+}$ in the samples was measured by inductively coupled plasma atomic emission spectroscopy. The photocatalytic activity of the La-doped $\mathrm{TiO}_{2}$ (LaT) was measured under UV light with the degradation of methyl orange (MO, $10 \mathrm{mg} / \mathrm{L}$ ). The results showed that the photocatalytic activity of $\mathrm{TiO}_{2}$ was enhanced remarkably by La-doping. LaT hydrothermally prepared with $0.15 \mathrm{~mol} / \mathrm{L} \mathrm{La}^{3+}$ at under 180 ${ }^{\circ} \mathrm{C}$ showed the optimal reaction constant of $0.11 \mathrm{~min}^{-1}$ for the degradation of MO, about 9.20 and 3.69 times than those of bare $\mathrm{TiO}_{2}$ and $\mathrm{P} 25$, respectively.
\end{abstract}

(c) 2013, Dalian Institute of Chemical Physics, Chinese Academy of Sciences. Published by Elsevier B.V. All rights reserved.

\section{Introduction}

Titania nanomaterials have attracted tremendous attention in the fields of photocatalysis and photoelectrochemistry [1-5]. Meanwhile, many studies have been performed on titanate functional materials, leading to the achievement of remarkable developments [6-9]. Layered titanate materials, such as $\mathrm{K}_{2} \mathrm{Ti}_{4} \mathrm{O}_{9}, \mathrm{~K}_{4} \mathrm{Nb}_{6} \mathrm{O}_{17}$, and $\mathrm{K}_{2} \mathrm{LaTi}_{3} \mathrm{O}_{10}[10,11]$, have extensive applications in photocatalysis. Their regular structure and designability show great potential for the adjustment of photo-reactivity on molecular and atomic levels. For example, modified $\mathrm{K}_{2} \mathrm{La}_{2} \mathrm{Ti}_{3} \mathrm{O}_{10}$ has shown better visible light absorption and superior photocatalytic activity for the degradation of organic dyes such as Rhodamine $\mathrm{B}$. Furthermore, $\mathrm{K}_{2} \mathrm{Ti}_{4} \mathrm{O}_{9}$ has also been used for $\mathrm{NO}_{x}$ storage, showing a high storage capacity

\section{$[12,13]$.}

Moreover, titanates have been recognized as useful precursors for the formation of $\mathrm{TiO}_{2}$ [14-16]. When hydrothermally treated in alkali or acid solution, titanate readily transforms into $\mathrm{TiO}_{2}$ of various morphology. When treated in $\mathrm{HNO}_{3}$ solution with a $\mathrm{pH}$ of $2-7, \mathrm{Na}_{2} \mathrm{Ti}_{2} \mathrm{O}_{5} \cdot \mathrm{H}_{2} \mathrm{O}$ nanobars transform into anatase nanobars [17], the anatase grain size of which enlarges with increasing $\mathrm{pH}$ of the hydrothermal solution. It has been proposed that the $\mathrm{H}^{+}$ions in the solution exchange with $\mathrm{Na}^{+}$ ions in the interlayers of the titanate [6], and the breakage and rearrangement of basic structural unit [ $\left.\mathrm{TiO}_{6}\right]$ octahedra leads to the formation of anatase nanocrystals. As the energy of the (001) facet is comparatively higher, the nanocrystal would grow along it to reduce the surface energy, leading to the formation of the anatase nanobars. Further works have shown

\footnotetext{
*Corresponding author. Tel: +86-21-64253056; Fax: +86-21-64252062; E-mail: fengchen@ecust.edu.cn This work was supported by the National Nature Science Foundation of China (20777015) and the Innovation Program of Shanghai Municipal Education Commission (13ZZ042).
} 
that the instability of titanates results from a large surface area, high amount of defects, and thin nanoplates, as well as poor rigidity, which are why it is able to transform to $\mathrm{TiO}_{2}$ [18].

By pre-protonating, titanates can also be transformed into anatase when hydrothermally treated in neutral $\mathrm{pH}$. Mao et al. [19] obtained anatase by hydrothermally treating protonated lepidocrocite type hydrogen titanate $\left(\mathrm{H}_{x} \mathrm{Ti}_{2-x / 4 x / 4} \mathrm{O}_{4}, \quad x\right.$ : $\sim 0.7$ :vacancy) in $\mathrm{pH} 7$ distilled water at $170{ }^{\circ} \mathrm{C}$. Bavykin et al. [20] observed the crystal phase evolution of titanate $\left(\mathrm{Na}_{x} \mathrm{H}_{2-x} \mathrm{Ti}_{3} \mathrm{O}_{7}\right)$ in various media including $\mathrm{H}_{2} \mathrm{O}, 0.1 \mathrm{~mol} / \mathrm{L} \mathrm{NaOH}$ $0.1 \mathrm{~mol} / \mathrm{L} \mathrm{H}_{2} \mathrm{SO}_{4}, 0.1 \mathrm{~mol} / \mathrm{L} \mathrm{HCl}$, and $0.1 \mathrm{~mol} / \mathrm{L} \mathrm{HNO}_{3}$, by aging titanate at room temperature for $5 \mathrm{~d}$ to 5 months. The crystal phase of the titanate did not change after aging in water or 0.1 $\mathrm{mol} / \mathrm{L} \mathrm{NaOH}$, but the titanate nanobars were decomposed, dissolved, and recrystallized into rutile $\mathrm{TiO}_{2}$ of $3 \mathrm{~nm}$ in size with oval morphology when they were treated in acidic solutions. The author suggested that titanate nanobars stayed in a state of thermodynamic stability in alkali solution and in a dynamics stability state in acidic solution. Further, a lower crystallization rate was in favor of the formation of thermodynamically stable rutile with a symmetrical structure.

Titanates appear likely to transform into $\mathrm{TiO}_{2}$ with special morphology under various conditions. Further, because the transformation process involves many factors, the transition mechanism from titanate to $\mathrm{TiO}_{2}$ is still an issue. In addition, many works have proved that La-doped $\mathrm{TiO}_{2}$ shows much better reactivity than blank samples [21,22]. Therefore, the introduction of La to a titanate system followed by hydrothermal treatment for the transition process would be a useful way to prepare La-doped $\mathrm{TiO}_{2}$. In this paper, $\mathrm{TiO}_{2}$ nanoparticles were prepared by treating titanate nanobars in acidic solution, and $\mathrm{La}^{3+}$ ions were introduced into the product to control the crystal phase and the photocatalytic performance of the as-prepared $\mathrm{TiO}_{2}$. The photocatalytic activity of the samples was examined via the degradation of methyl orange (MO, 10 $\mathrm{mg} / \mathrm{L}$ ) under UV light. Finally, the mechanism of the transition process and the role of $\mathrm{La}^{3+}$ in enhancing the photocatalytic activity were proposed.

\section{Experimental}

\subsection{Titanate preparation}

Titanate nanorods $\left(\mathrm{K}_{2} \mathrm{Ti}_{8} \mathrm{O}_{17}\right)$ were synthesized using a similar method to that previously published [23]. A certain amount of P25 was dissolved into $70 \mathrm{ml} \mathrm{KOH}$ aqueous solution of 7 mol/L concentration, and the mixture was stirred for several min before it was transferred into an autoclave $(100 \mathrm{ml})$ and treated at $180{ }^{\circ} \mathrm{C}$ for $72 \mathrm{~h}$. After it had cooled to room temperature, the solid precipitate in the liner was centrifuged and washed with $0.01 \mathrm{~mol} / \mathrm{L}$ hydrochloric acid and deionized water until the $\mathrm{pH}$ of the filtrate reached 7. The obtained white powder was dried at $80{ }^{\circ} \mathrm{C}$ in vacuum for $10 \mathrm{~h}$ and referred to as KTO.

\subsection{Synthesis of La-doped $\mathrm{TiO}_{2}$}

The KTO (2.0 g) was mixed with $30 \mathrm{ml} 0.1 \mathrm{~mol} / \mathrm{L} \mathrm{HNO}_{3}$ with stirring for $30 \mathrm{~min}$. Meanwhile, the desired amount of $\mathrm{La}\left(\mathrm{NO}_{3}\right)_{3} \cdot 6 \mathrm{H}_{2} \mathrm{O}\left(0-0.1 \mathrm{~mol} / \mathrm{L}\right.$ for $120{ }^{\circ} \mathrm{C}$ and $0-0.3 \mathrm{~mol} / \mathrm{L}$ for $180{ }^{\circ} \mathrm{C}$ ) was dissolved into $40 \mathrm{ml} 0.1 \mathrm{~mol} / \mathrm{L} \mathrm{HNO}_{3}$. The two solutions were then mixed together and hydrothermally treated at $120^{\circ} \mathrm{C}$ (or $180{ }^{\circ} \mathrm{C}$ ) for $48 \mathrm{~h}$. According to the different hydrothermal temperature, the final obtained samples were referred to as LaT-120- $x$ or LaT-180- $x$, where $x$ stands for the concentration of $\mathrm{La}^{3+} ; x=0$ corresponds to products prepared without $\mathrm{La}^{3+}$.

\subsection{Analysis and characterization}

\subsubsection{Catalyst characterization}

The crystalline phase of the products was examined by powder X-ray diffraction (XRD) using a RIGAKU D/max2550 operating in reflection mode with a Siemens D5000 diffractometer $\left(\mathrm{Cu} K_{\alpha}\right)$ at a scan rate of $0.02^{\circ} / \mathrm{s}$. Scanning electron microscopy (SEM, JEOL JSM-6360LV) was used to examine the morphologies and particle size of the samples. Transmission electron microscopy (TEM) of the samples was carried out using a JEOL JEM $2100 \mathrm{~F}$ operated at $200 \mathrm{kV}$. To prepare the TEM specimens, the powder samples were first ultrasonically dispersed in absolute ethanol and one or two drops of the suspension were the placed on a carbon film supported on a copper grid and dried in air before being transfer into the microscope. Inductively coupled plasma atomic emission spectroscopy (ICP-AES; TJA IRIS 1000) was used to measure the content of La element in the samples, for which the samples were dissolved in hydrogen fluoride (HF) solution before testing.

\subsubsection{Photocatalytic activity}

The UV photocatalytic activity of the composites was investigated for the photo-degradation of methyl orange (MO). UV irradiation was carried out using a $300 \mathrm{~W}$ high-pressure mercury lamp, which was surrounded by a quartz jacket to allow for water-cooling. An optical filter was used to cut off the light with wavelength longer than $390 \mathrm{~nm}$ to avoid the possible visible light induced dye photo-sensitized process. For a typical photocatalytic experiment, photocatalyst powder $(0.10 \mathrm{~g})$ was added to $100 \mathrm{ml}$ aqueous MO (10 mg/L) solution; after adjusting the $\mathrm{pH}$ of the solution to ca. 4.0 with $\mathrm{HCl}$ or $\mathrm{NH}_{3} \cdot \mathrm{H}_{2} \mathrm{O}$, the suspension was magnetically stirred in the dark for $30 \mathrm{~min}$ before UV illumination was conducted. The residual concentration of MO was then monitored by measuring its maximum absorbance with a UV-Vis spectrophotometer (Cary 100).

\section{Results and discussion}

\subsection{Characterization of KTO}

The XRD, TEM, HRTEM, and EDS results of KTO are shown in Figs. 1-3. The XRD pattern of the KTO matched well with previous reports [13] and the standard $\mathrm{PDF}$ of $\mathrm{K}_{2} \mathrm{Ti}_{8} \mathrm{O}_{17}$ (JCPDS 80-2023, space group: $\mathrm{C} 2 / \mathrm{m}(12))$. However, the diffraction peak of the KTO (200) plane was shifted slightly from $11.33^{\circ}$ to $10.80^{\circ}$. This may be ascribed to the intercalation of $\mathrm{H}_{2} \mathrm{O}$ mole- 


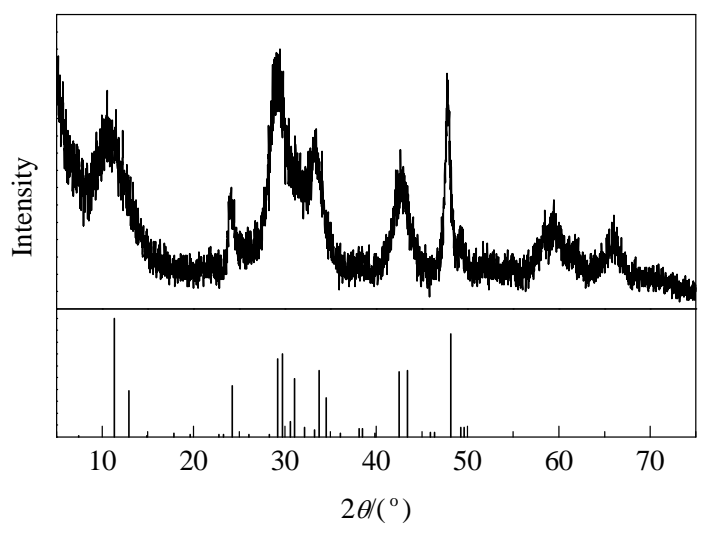

Fig. 1. XRD pattern of KTO product, the bar chart shows the standard XRD pattern of $\mathrm{K}_{2} \mathrm{Ti}_{8} \mathrm{O}_{17}$ (JCPDS 80-2023).

cules between the host layers of the titanate during the hydrothermal preparation, which slightly extended the layer space of the KTO. The peak shifted back to $11.33^{\circ}$ after KTO was calcined (data not shown). Figure 2 shows the EDS spectra of KTO, from which the elemental molar fraction of $\mathrm{K}$ and Ti was calculated as $1: 4$, which verified its chemical formula of $\mathrm{K}_{2} \mathrm{Ti}_{8} \mathrm{O}_{17}$. Figure 3 shows the TEM and HRTEM images of the KTO, respectively, which had a uniform nanobar morphology of ca. 100-150 nm length and ca. 15-20 nm width. The HRTEM image of KTO showed the layered structure of the samples; the nanobars grew along the [101] facet direction, and the interplanar spacing of the layers perpendicular to [101] was measured as $0.69 \mathrm{~nm}$, consistent with that of $(-201)$ of $\mathrm{K}_{2} \mathrm{Ti}_{8} \mathrm{O}_{17}$. Because the interlayer spacing of $(-201)$ is reported as $0.43 \mathrm{~nm}$ [24], while the radius of lanthanide series is within 0.085$0.105 \mathrm{~nm}$, it was considered possible for $\mathrm{La}^{3+}$ to enter the interlayers of the obtained titanate.

\subsection{Lattice evolution of products prepared with different hydrothermal temperatures and $\mathrm{La}^{3+}$ concentrations}

Figure 4 shows XRD patterns of $\mathrm{La}^{3+-}$ doped samples obtained by hydrothermal treatment of KTO at $120^{\circ} \mathrm{C}$ using various $\mathrm{La}^{3+}$ concentrations. When KTO was hydrothermally treated at $120{ }^{\circ} \mathrm{C}$, the $\mathrm{K}^{+}$in the interlayers of the titanate exchanged with $\mathrm{H}^{+}$in the solution, and thus condensation between the basic units $\left[\mathrm{TiO}_{6}\right]$ was greatly promoted and led to a lattice rearrangement to the anatase structure, which is relatively

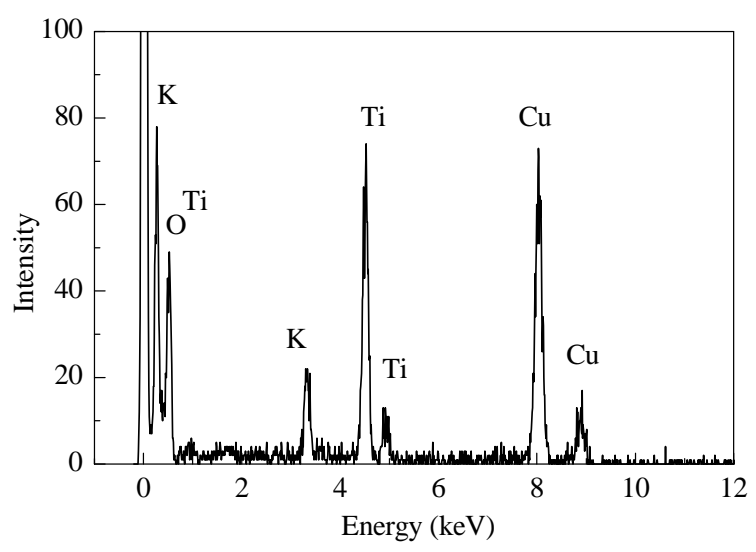

Fig. 2. EDS profile of KTO.

similar to that of the titanate [25]. Particularly, the energy needed to transition into anatase is much lower than that into rutile; therefore, anatase was the dominant phase in the products. However, there was still some residual titanate in the $\mathrm{La}^{3+}$-free sample (LaT-120-0), as shown in its XRD pattern (Fig. 4(1)). The introduction of $\mathrm{La}^{3+}$ appeared to promote the lattice transition, and complete lattice transition from titanate to anatase was observed for all $\mathrm{La}^{3+}$-doped samples (Fig. 4(2)-(6)). Whatever the concentration of $\mathrm{La}^{3+}$ used, the LaT products were pure and highly crystallized anatase.

Figure 5 shows XRD patterns of $\mathrm{La}^{3+}$-doped samples obtained by hydrothermal treatment of KTO at $180{ }^{\circ} \mathrm{C}$ using various $\mathrm{La}^{3+}$ concentrations. The $\mathrm{La}^{3+}$-free sample (LaT-180-0) presented as a mixture of anatase and rutile. The transition process was more violent at $180^{\circ} \mathrm{C}$ than that at $120^{\circ} \mathrm{C}$. Titanate and anatase have similar assemblies of octahedral [ $\left.\mathrm{TiO}_{6}\right]$ units, which each share four edges to form zigzag ribbon structures. Local dehydration occurs when layered titanate is hydrothermally treated in acid media, leading to rearrangement of local Ti-O-Ti bonds. The titanate transition to anatase generally progresses by rearrangement of lattice planes with shearing displacement along the (200) axis. Meanwhile, simultaneous lattice rearrangement in several directions is required when titanate transitions into rutile, which needs more energy [26]. Higher temperature and higher self-generated pressure provides adequate energy for the lattice transition to rutile, which accounts for the rutile phase observed in LaT-180-0, as shown in Fig. 5(1). The introduction of $\mathrm{La}^{3+}$ suppressed the transition from titanate into rutile; although an anatase and rutile mixture
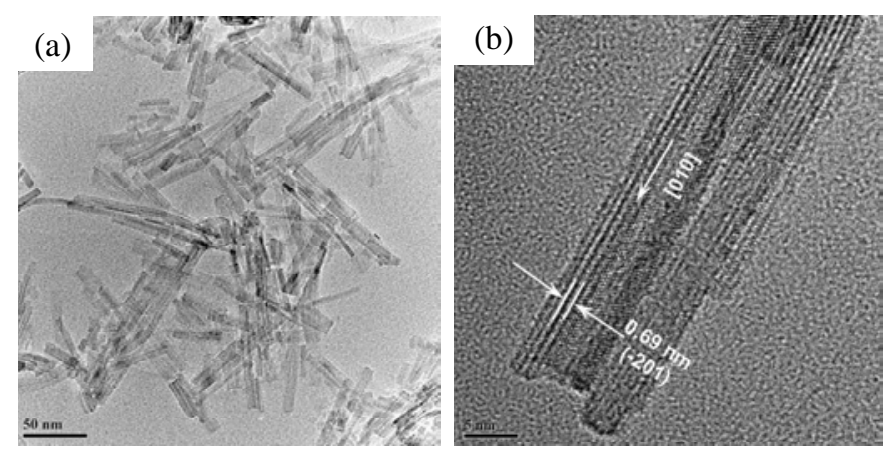

Fig. 3. TEM (a) and HRTEM (b) images of KTO. 


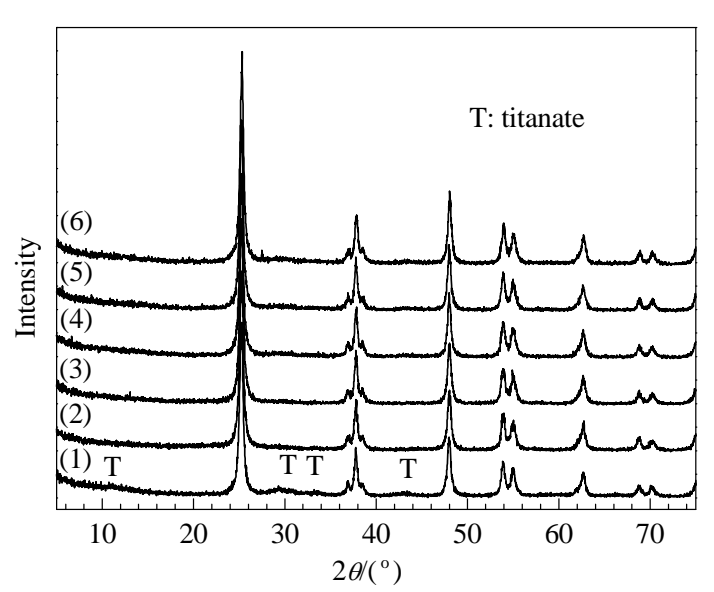

Fig. 4. XRD patterns of $\mathrm{La}^{3+}$-doped samples obtained by acid hydrothermal treatment at $120{ }^{\circ} \mathrm{C}$ with various $\mathrm{La}^{3+}$ concentrations. (1) LaT-120-0; (2) LaT-120-0.001; (3) LaT-120-0.003; (4) LaT-120-0.005; (5) LaT-120-0.01; (6) LaT-120-0.1

was obtained for the $\mathrm{La}^{3+}$-free product (LaT-180-0), only pure anatase was observed in products prepared in the presence of $\mathrm{La}^{3+}$.

TEM images of the La ${ }^{3+}$ doped samples are shown in Fig. 6. KTO presented typical nanobar morphology. After hydrothermal treatment in $0.1 \mathrm{~mol} / \mathrm{L} \mathrm{HNO}_{3}$ at $120{ }^{\circ} \mathrm{C}$, most of the nanobars ruptured to form nanoparticles, and consequently LaT-120-0 showed a mixture of nanobars and nanoparticles. According to the XRD patterns, it was obvious that the nanobars were titanate in phase and there nanoparticles were anatase phase. Increasing the temperature to $180^{\circ} \mathrm{C}$ promotes the morphological transition, and the TEM image of LaT-180-0 only exhibited nanoparticle-like morphology, as shown in Fig. 6(c). The morphology evolution process is actually induced by phase transition of titanate into $\mathrm{TiO}_{2}$. As shown, the XRD pattern of LaT-180-0 exhibited typical signals of an anatase/rutile mixture. When $\mathrm{La}^{3+}$ was introduced into the hydrothermal media, the morphology of products LaT-120-0.005 (Fig. 6(d)) and

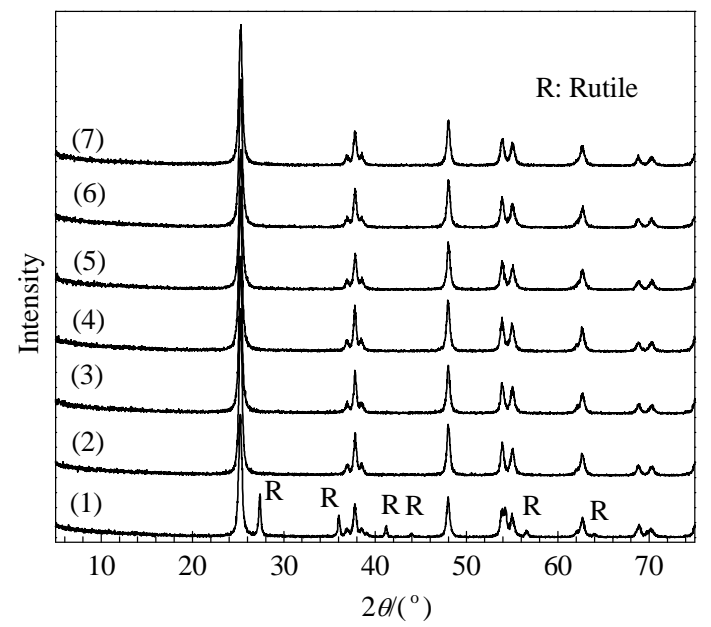

Fig. 5. XRD patterns of $\mathrm{La}^{3+}$-doped samples obtained by acidic hydrothermal treatment at $180{ }^{\circ} \mathrm{C}$ with various $\mathrm{La}^{3+}$ concentrations. (1) LaT-180-0; (2) LaT-180-0.005; (3) LaT-180-0.01; (4) LaT-180-0.1; (5) LaT-180-0.15; (6) LaT-180-0.2; (7) LaT-180-0.3.

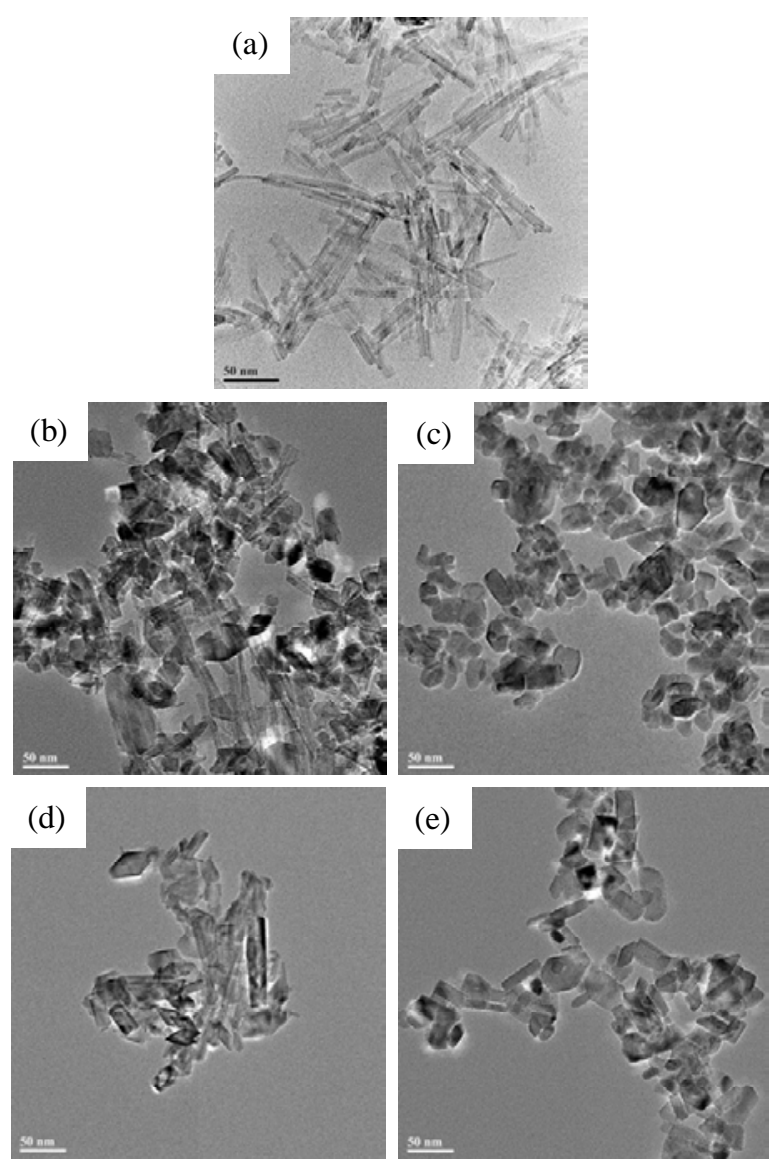

Fig. 6. TEM images of KTO (a), LaT-120-0 (b), LaT-180-0 (c), LaT-120-0.005 (d), and LaT-180-0.1 (e).

LaT-180-0.1 (Fig. 6(e)) was quite similar to that of sample LaT-180-0. The anatase grains (see XRD patterns in Figs. 4 and 5) observed were typical anisotropic nanoparticles with regular geometric shape, but not spheres. Their highly regular crystal morphology suggested that the obtained anatase was highly crystalline and thus may have good photocatalytic performance. The average grain sizes of the prepared LaTs were calculated with the Scherrer equation [27]:

$$
D=K \lambda / \beta \cos \theta
$$

where $\beta$ is the half-height width of the anatase diffraction peak, $K$ is a coefficient of $0.89, \theta$ is the diffraction angle, and is the $\mathrm{X}$-ray wavelength corresponding to $\mathrm{Cu} K_{\alpha}$ radiation. The results are listed in Table 1. The raised hydrothermal temperature significantly increased the grain size of the anatase, while the introduction of $\mathrm{La}^{3+}$ little changed the size little. The content of La in each sample, as tested by ICP-AES, is also shown in Table 1. The data show that the actual La content (wt\%) in the LaT-120- $x$ samples was comparatively higher than that in LaT-180- $x$ samples when the same $\mathrm{La}^{3+}$ concentration was used in the preparation of the $\mathrm{TiO}_{2}$. Most probably, as the $\mathrm{La}^{3+}$ ion has lower solubility at lower hydrothermal temperature, it was easier for it to form oxide clusters on the surface of the catalyst rather than embed in isolation. At higher hydrothermal temperature, $\mathrm{La}^{3+}$ ions were more disassociated into the aqueous solution and less embedded into the $\mathrm{TiO}_{2}$. Notably, $\mathrm{La}^{3+}$ ions were likely more effectively dispersed (but not in the form of 
Table 1

Calculated average anatase grain size and La content of LaT samples.

\begin{tabular}{lcc}
\hline Sample & Grain size ${ }^{a}(\mathrm{~nm})$ & Content of La ${ }^{\mathrm{b}}(\mathrm{wt} \%)$ \\
\hline LaT-120-0 & 19.1 & 0 \\
LaT-120-0.001 & 18.5 & 0.025 \\
LaT-120-0.003 & 19.0 & 0.048 \\
LaT-120-0.005 & 19.3 & 0.27 \\
LaT-120-0.01 & 19.8 & 0.31 \\
LaT-120-0.1 & 19.6 & 1.6 \\
LaT-180-0 & 23.6 & 0 \\
LaT-180-0.005 & 24.6 & 0.014 \\
LaT-180-0.01 & 23.9 & 0.067 \\
LaT-180-0.1 & 24.4 & 0.18 \\
LaT-180-0.15 & 22.1 & 0.19 \\
LaT-180-0.2 & 22.4 & 0.27
\end{tabular}

a Calculated by Scherrer equation.

${ }^{\mathrm{b}}$ Tested by ICP-AES.

oxide clusters) when embedded into the $\mathrm{TiO}_{2}$ at higher hydrothermal temperature, thus resulting in better photocatalytic performance (as shown in section 3.5).

\subsection{Effect of proton on the lattice transition}

The results above show that $\mathrm{KTO}$, that is $\mathrm{K}_{2} \mathrm{Ti}_{8} \mathrm{O}_{17}$, was able to transform into $\mathrm{TiO}_{2}$ via hydrothermal treatment at $\mathrm{pH}$ 1.0. Presumably, the loss of $\mathrm{K}^{+}$and dehydration by hydroxyl condensation was the key step in the lattice transition process. Hence, the KTO was also hydrothermally treated with $\mathrm{La}^{3+}$ at $120{ }^{\circ} \mathrm{C}$ at $\mathrm{pH} 4.0$ (using $0.1 \mathrm{mmol} / \mathrm{L} \mathrm{HNO}_{3}$ ), which contains much fewer $\mathrm{H}^{+}$ions as compared with $\mathrm{pH}$ 1.0. The XRD patterns of the as-obtained samples are presented in Fig. 7, which shows that the titanate structure was still remaining in the as-obtained samples (Fig. 7(1) and (2)). Compared with that occurring at $\mathrm{pH} 1.0$, the transition procedure from titanate to $\mathrm{TiO}_{2}$ at $\mathrm{pH} 4.0$ was definitely restrained. This result indicated that a sufficient amount of $\mathrm{H}^{+}$is indispensable for the lattice transition process. During the hydrothermal treatment, $\mathrm{H}^{+} \mathrm{ex}^{-}$ changed with $\mathrm{K}^{+}$in the interlayer, forming hydrogen titanate,

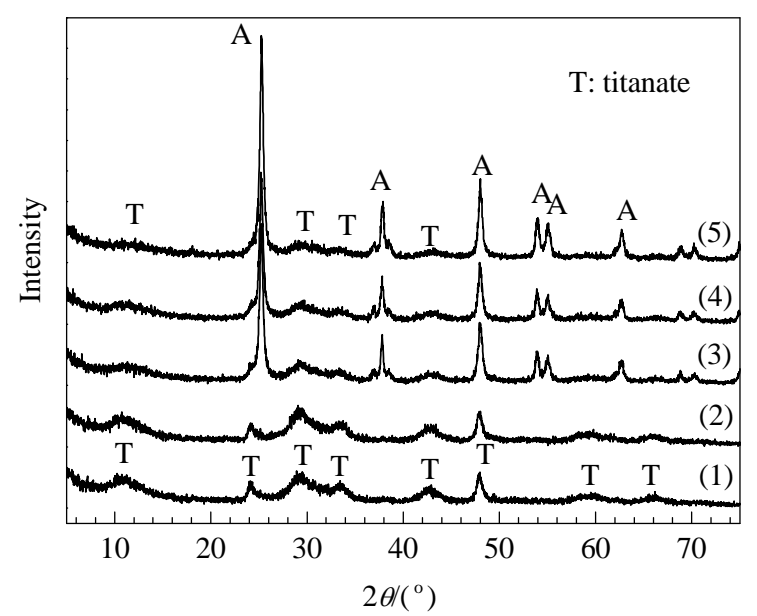

Fig. 7. XRD patterns of hydrothermally treated KTO with $0.01 \mathrm{~mol} / \mathrm{L}$ $\mathrm{La}^{3+}$ (1), $0.005 \mathrm{~mol} / \mathrm{L} \mathrm{La}^{3+}$ (2), hydrothermally treated $\mathrm{H}^{+}$ pre-exchanged KTO with $0.0025 \mathrm{~mol} / \mathrm{L} \mathrm{La}^{3+}$ (3), $0.005 \mathrm{~mol} / \mathrm{L} \mathrm{La}^{3+}$ (4), and $0.1 \mathrm{~mol} / \mathrm{L} \mathrm{La}^{3+}(5)$. Hydrothermal conditions: $120^{\circ} \mathrm{C}, \mathrm{pH} 4.0$. which is much easier to dehydrate during the transition to anatase.

$\mathrm{K}^{+}$deprivation can be partly achieved with careful $\mathrm{H}^{+}$ pre-exchange treatment in acidic solution. It has been reported that $\mathrm{Na}_{2} \mathrm{Ti}_{2} \mathrm{O}_{5} \cdot \mathrm{H}_{2} \mathrm{O}$ transforms into hydrogen dititanate when washed with acid [28], and hydrogen dititanate readily transforms into $\mathrm{TiO}_{2}$ upon hydrothermal or thermal treatment. Therefore, a pre-treating method was carried out. In a typical procedure, $2.0 \mathrm{~g}$ KTO was dispersed in $64 \mathrm{ml} \mathrm{HNO}_{3}$ (pH 1.0) for $0.5 \mathrm{~h}$, then filtered and hydrothermally treated with $\mathrm{La}^{3+}$ at 120 ${ }^{\circ} \mathrm{C}$ and pH 4.0. Figure 7(3)-(5) shows XRD patterns of the products of $\mathrm{H}^{+}$pre-exchanged KTO hydrothermally treated with $0.0025,0.005$, and $0.1 \mathrm{~mol} / \mathrm{L} \mathrm{La}^{3+}$, respectively.

Compared with samples that did not undergo the $\mathrm{H}^{+}$ pre-exchange procedure (Fig. 7(1) and (2)), the amount of titanate phase in the samples prepared with the $\mathrm{H}^{+}$pre-exchange procedure decreased to a very low level while the anatase content greatly increased. The $\mathrm{H}^{+}$ions play a dominant role in the lattice transition. $\mathrm{H}^{+}$ions exchange with $\mathrm{K}^{+}$ions in the titanate interlayer, and then carry out a dehydration procedure to initiate the merging of the two host layers to form $\mathrm{TiO}_{2}$ under hydrothermal treatment. Although the $\mathrm{H}^{+}$pre-exchange procedure greatly aided the removal of $\mathrm{K}^{+}$from the interlayers, complete $\mathrm{K}^{+}$deprivation appeared to only be achieved by hydrothermal treatment, because ion-exchange is promoted under hydrothermal conditions.

\subsection{Schematic illustration of the transition process}

A schematic illustration of the transition process from KTO to titania for different procedures is shown in Fig. 8. When hydrothermally treated in $\mathrm{HNO}_{3}$ solution of $\mathrm{pH} 1$, the large amounts of $\mathrm{H}^{+}$in the solution readily exchange with $\mathrm{K}^{+}$in the interlayers of the titanate to form protonated titanate (HTO) instead of KTO. HTO is a more metastable phase and tends to undergo a dehydration process to transition into anatase. However, at pH 4.0, the much lower $\mathrm{H}^{+}$concentration leads to insufficient exchange between $\mathrm{K}^{+}$and $\mathrm{H}^{+}$, which means that most $\mathrm{K}^{+}$ions remain in the interlayers of the titanate, thus making it difficult to transform from KTO to $\mathrm{TiO}_{2}$. $\mathrm{A} \mathrm{H}^{+}$ pre-exchange process greatly helps to remove the $\mathrm{K}^{+}$in the

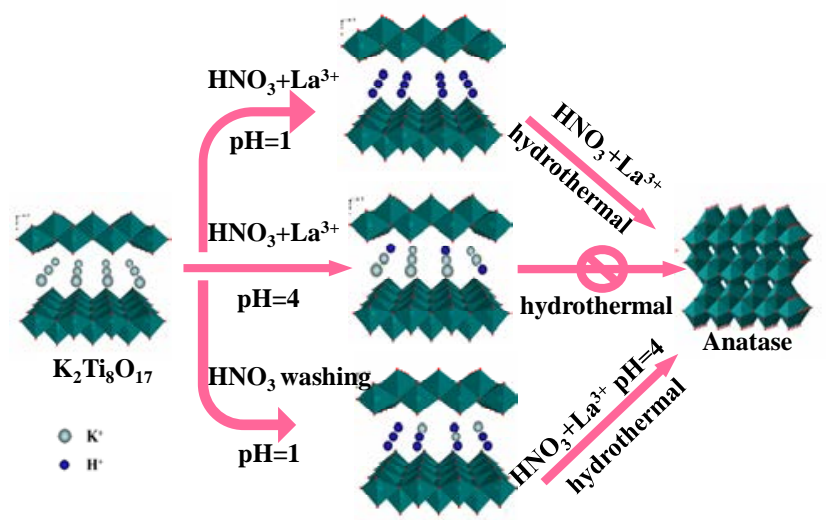

Fig. 8. Schematic illustration of the transition process from KTO to titania for different procedures. 
interlayers. Thus, when treated in $\mathrm{HNO}_{3}$ solution at $\mathrm{pH} 1, \mathrm{~K}^{+}$in the interlayers of KTO exchanges with the high concentration of $\mathrm{H}^{+}$, and a similar dehydration process occurs to produce anatase phase $\mathrm{TiO}_{2}$ under the subsequent hydrothermal treatment. However, the ion-exchange ability of the $\mathrm{H}^{+}$pre-exchange process occurring at room temperature is much weaker than that under hydrothermal treatment (at 120 and $180{ }^{\circ} \mathrm{C}$ ), and thus the products obtained in this way (Fig. 7(3)-(5)) were universally a mixture of anatase and a small amount of titanate, i.e., KTO did not completely transition to $\mathrm{TiO}_{2}$.

\subsection{Photocatalytic activity of La-doped $\mathrm{TiO}_{2}$}

The process of MO degradation of the samples to MO appeared to follow apparent first-order kinetics. The photocatalytic degradation of MO with various LaT-120- $x$ samples and the corresponding MO degradation reaction constants for the various $\mathrm{La}^{3+}$ concentrations used are shown in Fig. 9 and Table 2. The degradation rates differed widely with $\mathrm{La}^{3+}$ concentration. It is clear that the degradation rates of most of the La-doped samples, except those with a too great $\mathrm{La}^{3+}$ concentration (i.e. 0.01 and 0.1 ), were greatly enhanced by $\mathrm{La}^{3+}$ doping (Fig. 9). The MO degradation reaction constants increased obviously when the $\mathrm{La}^{3+}$ concentration was increased from 0 to $0.003 \mathrm{~mol} / \mathrm{L}$, while it decreased when the concentration was increased from 0.003 to $0.1 \mathrm{~mol} / \mathrm{L}$, with optimal activity at $0.003 \mathrm{~mol} / \mathrm{L}$ (Table 2). Notably, all LaT-120- $x$ samples except that with $0.1 \mathrm{~mol} / \mathrm{L} \mathrm{La}^{3+}$ showed much higher MO degradation reaction constants than that of P25. Particularly, the MO deg-

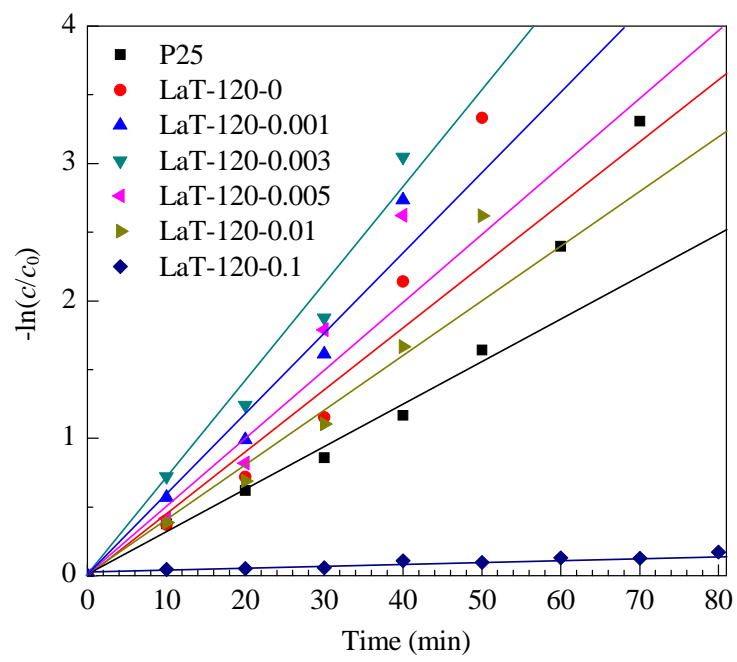

Fig. 9. Photocatalytic degradation of MO over LaT-120- $x$ samples and P25 $\mathrm{TiO}_{2}$ under UV irradiation.

Table 2

The degradation reaction constant of MO vs. $\mathrm{La}^{3+}$ concentration used in the hydrothermal preparation of LaT-120- $x$ samples.

\begin{tabular}{lc}
\hline Concentraion of $\mathrm{La}^{3+}(\mathrm{mol} / \mathrm{L})$ & $k / \mathrm{min}^{-1}$ \\
\hline 0 & 0.038 \\
0.001 & 0.054 \\
0.003 & 0.063 \\
0.005 & 0.060 \\
0.01 & 0.037 \\
0.1 & 0.002 \\
\hline
\end{tabular}

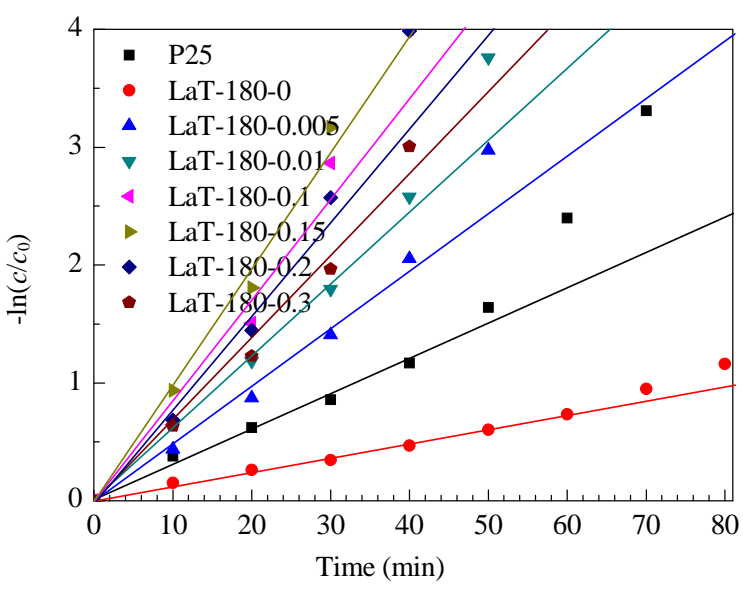

Fig. 10. Photocatalytic degradation of MO over LaT-180- $x$ samples and P25 $\mathrm{TiO}_{2}$ under UV irradiation.

Table 3

The degradation reaction constant of MO vs. $\mathrm{La}^{3+}$ concentration used for the hydrothermal preparation of the LaT-180- $x$ samples.

\begin{tabular}{lc}
\hline Concentraion of $\mathrm{La}^{3+}(\mathrm{mol} / \mathrm{L})$ & $k / \mathrm{min}^{-1}$ \\
\hline 0 & 0.011 \\
0.005 & 0.047 \\
0.01 & 0.060 \\
0.1 & 0.096 \\
0.15 & 0.106 \\
0.2 & 0.086 \\
0.3 & 0.065 \\
\hline
\end{tabular}

radation reaction constant of LaT-120-0.003 (0.063 $\left.\mathrm{min}^{-1}\right)$, the optimal, was almost 2.19 times that of P25 (0.028 $\left.\mathrm{min}^{-1}\right)$. Therefore, the addition of $\mathrm{La}^{3+}$ in this work not only promoted the transition process from titanate to anatase (as shown by XRD), but also improved the separation of photogenerated electrons and holes which largely contribute to enhance the photoactivity. Under hydrothermal treatment, $\mathrm{La}^{3+}$ likely combined onto the surface of the $\mathrm{TiO}_{2}$ and may even have occupied surface defects, thus improving carrier separation during the photocatalytic process to enhance the activity of the photocatalysts. However, when the $\mathrm{La}^{3+}$ concentration of was excessively high, the over-enriched $\mathrm{La}^{3+}$ likely form additional metal oxide clusters, which normally act as recombination centers for photogenerated electrons and holes, thus reducing the photocatalytic activity of the $\mathrm{TiO}_{2}$.

The photodegradation of MO with various LaT-180- $x$ (Fig. 10) samples and the corresponding MO degradation reaction constant with $\mathrm{La}^{3+}$ concentration used (Table 3) were also investigated. Degradation rates for all $\mathrm{La}^{3+}$ doped significantly exceeded those of P25 and the $\mathrm{La}^{3+}$-free sample LaT-180-0, which means that La-doping had an obviously positive effect on the photocatalytic activity of the samples. Table 3 shows the relationship of MO degradation reaction constant to $\mathrm{La}^{3+}$ concentration. When $\mathrm{La}^{3+}$ concentration was increased from 0 to $0.15 \mathrm{~mol} / \mathrm{L}$, the reaction constants also significantly increased before decreasing when the $\mathrm{La}^{3+}$ concentration was further increased from 0.15 to $0.3 \mathrm{~mol} / \mathrm{L}$. The reaction constants of all La-doped samples were much larger than those of the $\mathrm{La}^{3+}$-free sample (LaT-180-0) and P25. The optimal reaction constant at 
$0.15 \mathrm{~mol} / \mathrm{L} \mathrm{La}^{3+}\left(0.11 \mathrm{~min}^{-1}\right)$ was about 9.20 times greater than that of LaT-180-0 and 3.69 times greater than that of P25 $\left(0.029 \mathrm{~min}^{-1}\right)$. Besides promoting the separation of photogenerated electrons and holes, the $\mathrm{La}^{3+}$ restrained the transition of titanate into rutile to induce the formation of pure anatase (as shown by XRD), likely also significantly contributed to the enhanced photocatalytic activity of the LaT-180- $x$ samples.

\section{Conclusions}

The photodegradation of MO with various LaT-180- $x$ (Fig. $10(\mathrm{a})$ ) samples and the corresponding MO degradation reaction constant with $\mathrm{La}^{3+}$ concentration used (Fig. 10(b)) were also investigated. Degradation rates for all $\mathrm{La}^{3+}$ doped significantly exceeded those of P25 and the $\mathrm{La}^{3+}$-free sample LaT-180-0, which means that La-doping had an obviously positive effect on the photocatalytic activity of the samples. Figure 10(b) shows the relationship of MO degradation reaction constant to $\mathrm{La}^{3+}$ concentration. When $\mathrm{La}^{3+}$ concentration was increased from 0 to $0.15 \mathrm{~mol} / \mathrm{L}$, the reaction constants also significantly increased before decreasing when the $\mathrm{La}^{3+}$ concentration was further increased from 0.15 to $0.3 \mathrm{~mol} / \mathrm{L}$. The reaction constants of all La-doped samples were much larger than those of the $\mathrm{La}^{3+}$-free sample (LaT-180-0) and P25. The optimal reaction constant at $0.15 \mathrm{~mol} / \mathrm{L} \mathrm{La}^{3+}\left(0.11 \mathrm{~min}^{-1}\right)$ was about 9.20 times greater than that of LaT-180-0 and 3.69 times greater than that of P25 $\left(0.029 \mathrm{~min}^{-1}\right)$. Besides promoting the separation of photogenerated electrons and holes, the $\mathrm{La}^{3+}$ restrained the transition of titanate into rutile to induce the formation of pure anatase (as shown by XRD), likely also significantly contributed to the enhanced photocatalytic activity of the LaT-180- $x$ samples.

\section{References}

[1] Fujishima A, Honda K. Nature, 1972, 37: 238

[2] Fujishima A, Rao T N, Tryk D A. J Photochem Photobiol C, 2000, 1: 1

[3] Mahmood T, Wang X S, Chen C C, Ma W H, Zhao J C. Chin J Catal (塔
里克, 王雪松, 陈春城, 马万红, 赵进才. 催化学报), 2007, 28: 1117

[4] Li H X, Zhu J. Chin J Catal (李和兴, 朱建. 催化学报), 2008, 29: 91

[5] Chen X B. Chin J Catal (陈晓波. 催化学报), 2009, 30: 839

[6] Li N, Zhang L D, Chen Y Z, Fang M, Zhang J X, Wang H M. Adv Funct Mater, 2012, 22: 835

[7] Qian D N, Xu B, Cho H M, Hatsukade T, Carroll K J, Meng Y S. Chem Mater, 2012, 24: 2744

[8] Xiao M, Wang X, Zhang Q Q Ding H M. Chin J Inorg Chem, 2012, 28: 1743

[9] Lu R, Jiang G S, Li B, Zhao Q L, Zhang D Q, Yuan J, Cao M S. Chin Phys Lett, 2012, 29: 058101

[10] Huang Y, Wu J, Li T, Hao S, Lin J. J Porous Mater, 2006, 13: 55

[11] Cui W Q, Qi Y L, Hu J S, Liu L, Liang Y H. Acta Chim Sin, 2012, 70: 691

[12] Kumar V, Govind, Uma S.J Hazard Mater, 2011, 189: 502

[13] Shen W H, Nitta A, Chen Z, Eda T, Yoshida A, Naito S. J Catal, 2011, 280: 161

[14] Zhao B, Chen F, Huang Q, Zhang J. Chem Commun, 2009: 5115

[15] Zhao B, Chen F, Jiao Y, Yang H, Zhang J. J Mol Catal A, 2011, 348: 114

[16] Jiao Y, Zhao B, Chen F, Zhang J. CrystEngComm, 2011, 13: 4167

[17] Nian J N, Teng H.J Phys Chem B, 2006, 110: 4193

[18] Zhu H Y, Lan Y, Gao X P, Ringer S P, Zheng Z F, Song D Y, Zhao J C.J Am Chem Soc, 2005, 127: 6730

[19] Mao Y B, Wong S S. J Am Chem Soc, 2006, 128: 8217

[20] Bavykin D V, Friedrich J M, Lapkin A A, Walsh F C. Chem Mater, 2006, 18: 1124

[21] Zhao Q H, Quan X J, Tan H Q, Sang X M. Chin J Catal (赵清华, 全学 军, 谭怀琴, 桑雪梅. 催化学报), 2008, 29: 269

[22] Wei W, Dai Y, Guo M, Yu L, Huang B B. J Phys Chem C, 2009, 113: 15046

[23] Kasuga T, Hiramatsu M, Hoson A, Sekino T, Niihara K. Adv Mater, 1999, 11: 1307

[24] Cao J C, Wang A L, Yin H B, Shen L Q, Ren M, Han S Q, Shen Y T, Yu L B, Jiang T S. Ind Eng Chem Res, 2010, 49: 9128

[25] Li J G, Ishigaki T, Sun X.J Phys Chem C, 2007, 111: 4969

[26] Xu J S, Zhang H, Li W B, Zhang J, Liu X Y, He X K, Xu D L, Qian J H, Liu L. Micro Nano Lett, 2012, 7: 654

[27] Wu Y, Liu H, Zhang J, Chen F. J Phys Chem C, 2009, 113: 14689

[28] Tsai C-C, Teng H. Chem Mater, 2006, 18: 367

\section{Graphical Abstract}

Chin. J. Catal., 2013, 34: 585-592 doi: 10.1016/S1872-2067(11)60483-X

La-doped titania nanocrystals with superior photocatalytic activity prepared by hydrothermal method

JIAO Yanchao, ZHU Mingfeng, CHEN Feng*, ZHANG Jinlong East China University of Science and Technology

$\mathrm{La}^{3+}$ doped $\mathrm{TiO}_{2}$ was prepared by treating $\mathrm{K}_{2} \mathrm{Ti}_{8} \mathrm{O}_{17}$ in acidic solution. $\mathrm{TiO}_{2}$ doped with $0.15 \mathrm{~mol} / \mathrm{L} \mathrm{La}^{3+}$ gave the optimal reaction constant of $0.11 \mathrm{~min}^{-1}$ for methyl orange degradation, about 9.20 times that of bare $\mathrm{TiO}_{2}$.

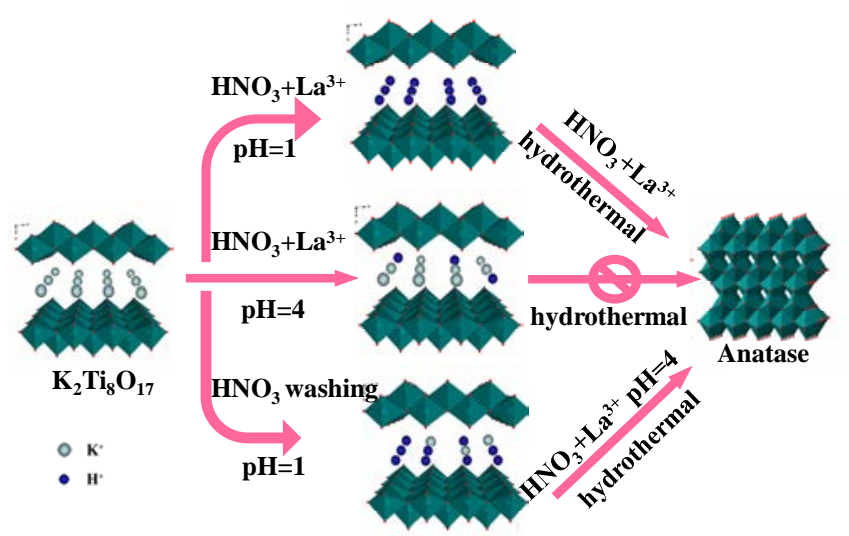




\title{
水热法制备具有高光催化活性的镧掺杂二氧化钛纳米晶
}

\author{
焦艳超，朱明峰，陈 锋*，张金龙 \\ 华东理工大学先进材料重点实验室和精细化工研究所, 上海 200237
}

摘要: 采用水热法合成钛酸钾 $\left(\mathrm{K}_{2} \mathrm{Ti}_{8} \mathrm{O}_{17}\right)$ 纳米棒, 并将它作为前驱体水热转晶合成 $\mathrm{TiO}_{2}$ 纳米晶, 同时通过在水热体系中引入稀土 元素 $\mathrm{La}^{3+}$ 实现对 $\mathrm{TiO}_{2}$ 的 $\mathrm{La}$ 掺杂. 考察了不同条件下钛酸盐向 $\mathrm{TiO}_{2}$ 的转晶过程, 发现水热溶液的 $\mathrm{pH}$ 值、温度以及预处理步骤对 转晶过程有很大的影响. 利用 $\mathrm{X}$ 射线衍射以及透射电子显微镜对样品的晶相和形貌进行了表征. 利用电感耦合等离子体原子发 射光谱测量了所合成的 $\mathrm{La}$ 掺杂 $\mathrm{TiO}_{2}$ 样品中的 $\mathrm{La}$ 含量. 通过在紫外光下降解甲基橙 $(\mathrm{MO}, 10 \mathrm{mg} / \mathrm{L})$ 测试了 $\mathrm{La}$ 掺杂 $\mathrm{TiO}_{2}$ 样品的 光催化性能. 结果表明 $\mathrm{La}$ 掺杂后 $\mathrm{TiO}_{2}$ 的光催化活性大大提高. 在 $0.15 \mathrm{~mol} / \mathrm{L} \mathrm{La}^{3+}$ 浓度下 $180 \mathrm{oC}$ 水热合成的 $\mathrm{La}$ 掺杂 $\mathrm{TiO}_{2}$ 样品 显示了最佳的光催化活性. 其对 $\mathrm{MO}$ 的光催化降解反应常数高达 $0.11 \mathrm{~min}^{-1}$, 大约是空白 $\mathrm{TiO}_{2}$ 样品的 9.20 倍, $\mathrm{P}^{2} 5 \mathrm{TiO}_{2}$ 的 3.69 倍.

关键词: 八钣酸钾; 相转变; 镧掺杂二氧化钛; 光催化活性; 水热合成

收稿日期: 2012-10-15. 接受日期: 2012-11-10. 出版日期: 2013-03-20.

*通讯联系人. 电话: (021)64253056; 传真: (021)6425206; 电子信箱: fengchen@ecust.edu.cn

基金来源：国家自然科学基金 (20777015); 上海市教委科研创新项目 (13ZZ042).

本文的英文电子版(国际版)由Elsevier出版社在ScienceDirect上出版(http://www.sciencedirect.com/science/journal/18722067). 